\title{
Soil-landscape and climatic relationships in the middle Miocene of the Madrid Basin
}

\author{
A. M. A LONSO ZARZA*, V. P. W R IGHTt, J . P . CA L VO* and \\ M. A. GA RCIA DEL CURA * \\ *U.E.I. Petrología. Instituto de Geologia Económica, CSIC, Universidad Complutense, 28040 Madrid, \\ Spain \\ tPostgraduate Research Institute for Sedimentology, The University,PO Box227. Whirek11igh1s, Reading \\ $R G 62 A B$, \\ UK
}

\begin{abstract}
The Miocene alluvial-lacustrine sequences of the Madrid Basin, Spain, fonned in highly va.ried landscapes. The presence of various types of palacosols allows assessment of the effects of local and externat factors on sedimentation, pedogenesis and geomorphological devclopment. In the northern, more arid, tectonically act ive area, soils were weak ly developed in aggrading alluvial fans, dominated by mass flows, reflecting high sedimentation rates. In more distal parts of the fans and in playa lakes calcretes and dolocretes dcvcloped; the former were associated with Mg-poor fan sediments while the latter fonned on Mg-rich lake clays exposed during minor lake lowstands.

The nonh-east part of the basin had a less arid climate. Alluvial fans in this area were dominated by stream flood deposits, sourccd by carbonate terrains. Floodplain and freshwater lake deposits fonned in distal areas. The high local supply of calcium carbonate may have contributed to the preferential development of calcreteson the fans.Both the fan and flood plain palaeosolsexhibit pedofacies relationships and more mature soils developed in settings more distant from the sediment sources. Palae-0sols also developed on pond and lake margin carbonates, and led to the formation of palustrinc limestones.

The spatial distributions and stratigraphies of palaeosols in the Madrid Basin alluvial fans suggest that soil formation was controlled by local factors.These palaeosols differ from those seen in Quatemary fans, which are characterized by climatically induced periodsof stability and instability.
\end{abstract}

\section{INTRODUCT I ON}

Soils are integral parts of landscapes and are highly sensitive to changes in that landscape. Fossil soils (palaeosols) can provide information on palaeolandscapes and integrating analyses of palaeosols and facies can provide new insights into the geomorphology of ancient deposystems. Recently, several studies of palaeosols in alluvial and deltaic sequences have recognized specific geomorphologically controlled catenary (slope/drainage) and pedofacies relation- ships (e.g. Brown \& Kraus, 1987; Besly \& Fielding, 1989; Smith, 1990), and in this paper we attempt to look at palaeosol/palaeolandscape relationships on a large scale.

The middle Miocene of the Madrid Basin, Spain, consists of a well-ex-posed alluvial and lacustrine sequence which developed in varied landscapes of two distinct geomorphological regions, each with different bedrock geology, tectoniesetting, topography and climate.

In this paper we relate the varied suite of palaeosols, especially tbeir mineralogies and maturities, to their positions within the Miocene landscapes. In doing so it is possi ble to assess the relative rotes of local factors versus extrinsic ones, such as climatic change, in controlling the broader-scale distribution $\mathrm{s}$ and sequences of palaeosols in the fan deposits.

\section{GEOLOG ICA L FRA MEWOR K}

The Madrid Basin forms the major part of the Tajo Basin, one of three large continental basins which 


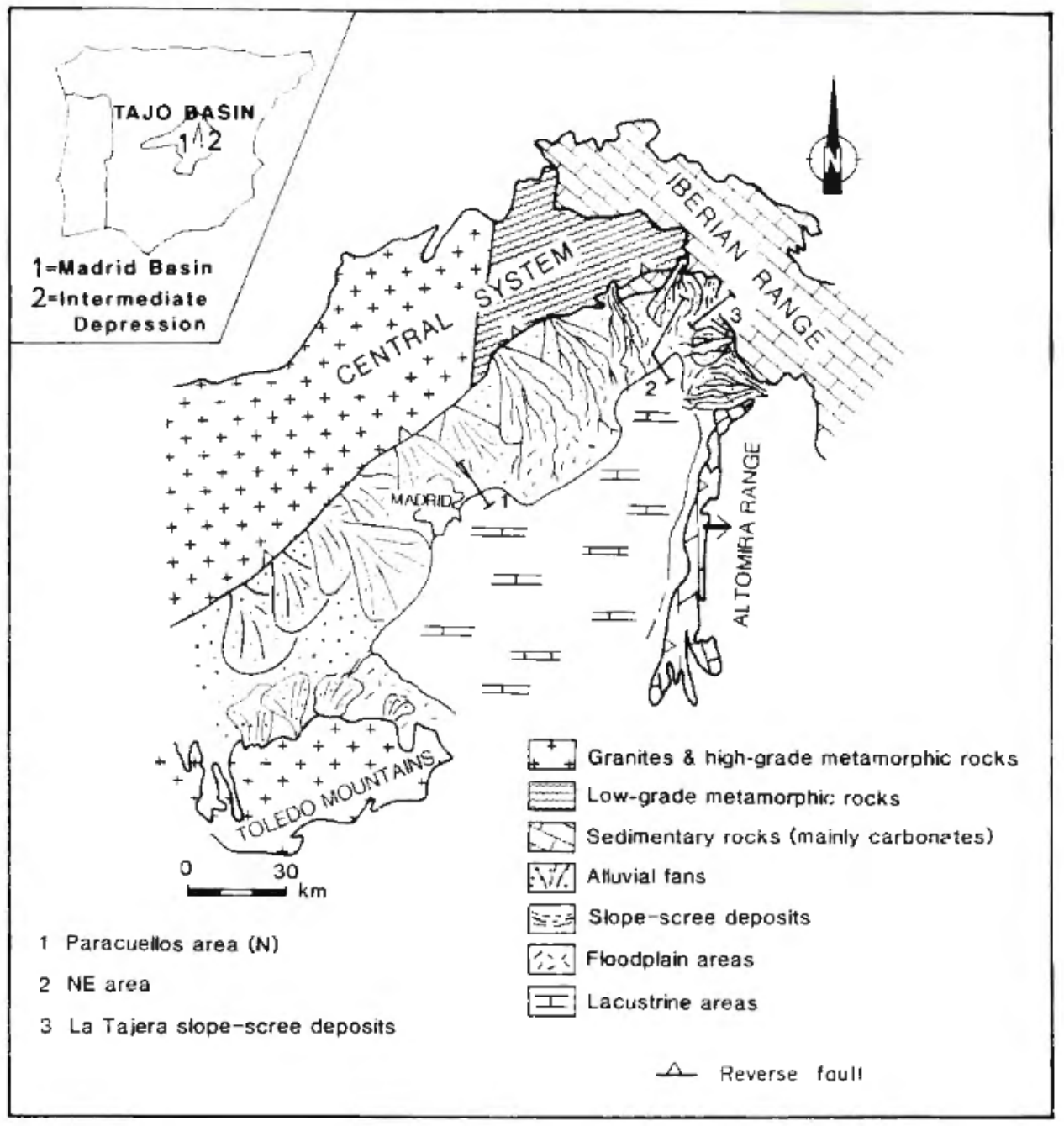

Fig. 1. Location of the Madrid Basin (inset) and schematic representation of depositional systems during the deposition of the Miocene Intermediate Unit. 1-3 are the study a.reas: 1 =northem area; 2 =alluvial fan floodplain area in the north east area; 3=scree deposits, north east area (La Tajera).

developed in the Iberian Peninsula during the Tertiary (Fig. 1). The basin is bounded by different types of fault systems which were active during compressive alpine movements. High-angle reverse faults were active from the Palaeogene to the middle Miocene at the northem margin of the basin; the southern and north eastern borders were, in general, characterized by Jessactive normal faulting ; the faults on the eastern margin of the basin (Altomira Range) were only active during late Palaeogene and early Miocene times (Calvo et al., 1989; De Vicente et al., 1990).
These fault systems separated the basin from adjacent upland source areas, which were lithologycally highly varied (Fig. 1). Granites and highgrade metamorphic rocks formed the area of high relief (the Central System, Sistema Central) in the north. Lowgrade metamorphic rocks and sedimentary rocks formed lower relief margins in the easternmost part of the Central System (Somosierra) and the Iberian Range respectively. Sedimentary rocks (mainly Jurassic-Cretaceous c-arbonates) were exposed in the easlern part of the basin (Iberian and Altomira 


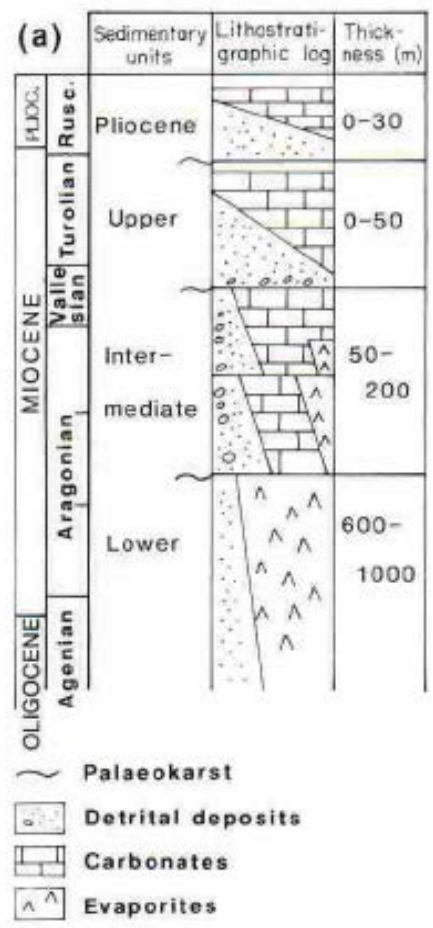

(b)

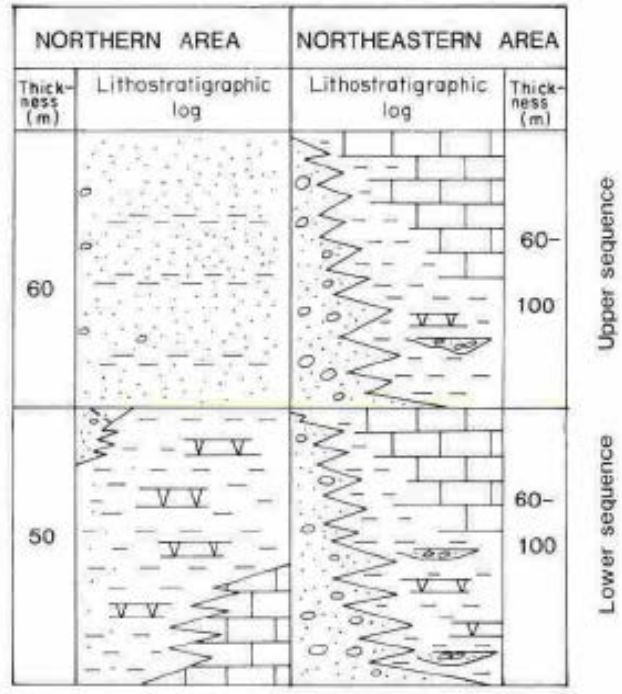

Coarse detrital deposits (proximal and medial fan facies)

Fine detrital deposits (distal fan facies and flood plains)

Clays and carbonates (lacustrine deposits)

Fig. 2. (a) Stratigraphy of the Neogene sequence in the Madrid Basin.(b) Stratigraphy of the Intermediate Unit in the Madrid Basin contrasting the sequences in the north and north·eastern areas.

ranges). The Toledo Mountains to the south are composed mainly of granites and high-grade metamorphic rocks.

The Tertiary fill of the Madrid Basin comprises more than $3500 \mathrm{~m}$ of continental deposits which have been recognized from deep boreholes as well as from seismic profùes (Junco \& Calvo, 1983 ; Megias et al., 1983; Racero, 1988). In this continental sequence Neogene deposits include (Fig. 2):

(a) an early Miocene, mainly evaporite sequence (600-1000 m thick) with theuard ite, glauberi te, halite, anhydrite and gypsum.These deposits have been assigned to the Miocene Lower Unit of the Madrid Basin (Garcia del Cura et al., 1979, 1986). They range from Agenian to middle Aragon ian in age (AquitanianBurdigalian) (Fig. 2a); (b) a middle Miocene unit consisting of clastic, carbonate and evaporite deposits, up to $200 \mathrm{~m}$ thick (Fig. 2b). These deposits are included in the Miocene Intermediate Unit (Junco \& Calvo, 1983; Alberdi et al., 1983) and are middle Aragonian to early Vallesian (Langhian to early Tortonian) in age (Fig. 2a);

(c) a late Miocene clastic and carbonate sequence overlying the Intermediate Unit, referred to as the Miocene Upper Un it. It is up to $50 \mathrm{~m}$ in thickness and has been considered to be of early Vallesian to late Turolian (Late Tortonian to Messinian) in age (Fig. 2a);

(d) the Pliocene sequence of continental clastics and carbonates forms the final fill of the basin.

These units have erosive and/or karstic boundaries 


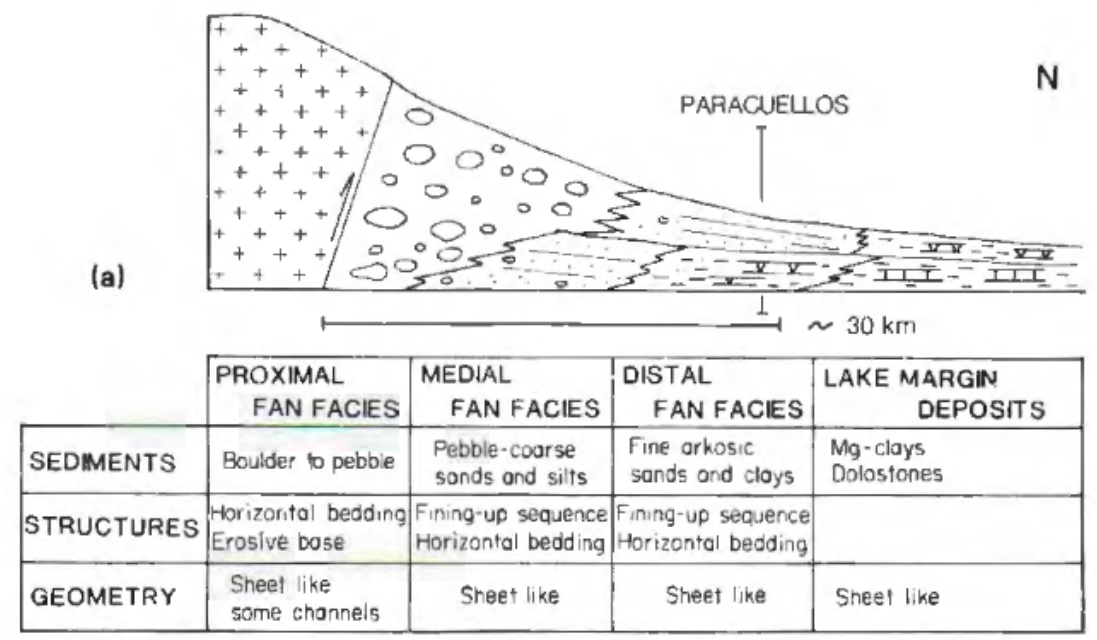

(b)

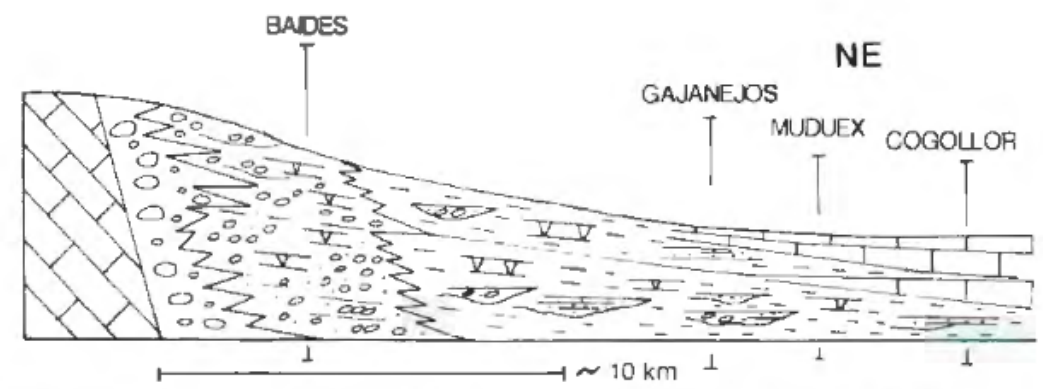

\begin{tabular}{|c|c|c|c|c|}
\hline & $\begin{array}{l}\text { PROXIMAL } \\
\text { FAN FACIES }\end{array}$ & $\begin{array}{l}\text { MEDIAL } \\
\text { FAN FACIES }\end{array}$ & $\begin{array}{r}\text { DISTAL FAN FACIES } \\
\& \text { FLOODPLAINS }\end{array}$ & $\begin{array}{l}\text { LAKE MARGIN } \\
\text { DEPOSITS }\end{array}$ \\
\hline SEDIMENTS & Boulder to cobble & Cobble to Pebble & $\begin{array}{l}\text { Cobble-pebble, sonds } 8 \\
\text { red mudstones }\end{array}$ & Limestones \\
\hline STRUCTURES & \begin{tabular}{|l|l|}
$\begin{array}{l}\text { Horizontal } \\
\text { bedding }\end{array}$ \\
\end{tabular} & $\begin{array}{l}\text { Herizontal bedating } \\
\text { Erosive bases } \\
\text { mibrication }\end{array}$ & 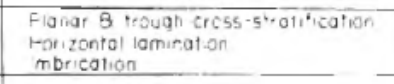 & \\
\hline GEOMETRY & Sheet like & Sneet like & Sheet like $\mathbf{8}$ chonnels & Sheet like \\
\hline
\end{tabular}

Fig. 3.Longitudinal schematic facies transectscontrasting the north (a)and north-ea stern (b)areas, illustrating the relationships between the alluvial fan and lacustrine deposits. Sedimentological logs from the marked local ities are given in Fig.4.

(Ordoiiez el al., 1985) and relate to tectonic acti vity in the basin (Megias, 1982).

The Miocene lntermediate U nit, which includes the palaeosols discussed in this paper, shows a great variety of lithofacies with $\mathrm{n}$ the basin. Two contrasting areas are described in tbis paper, each displaying different assemblages of palaeosols. These areas are the northem part of the basin located around Madrid (area 1 on Fig. 1) and the north-eastern area (areas 2 \& 3 on Fig. 1).

\section{Northern region}

Miocene clastic deposits in the northern area extend south-west and north-west of Madrid (Fig. 1), and the thickness of the Intermediate Unit reaches $110 \mathrm{~m}$. 


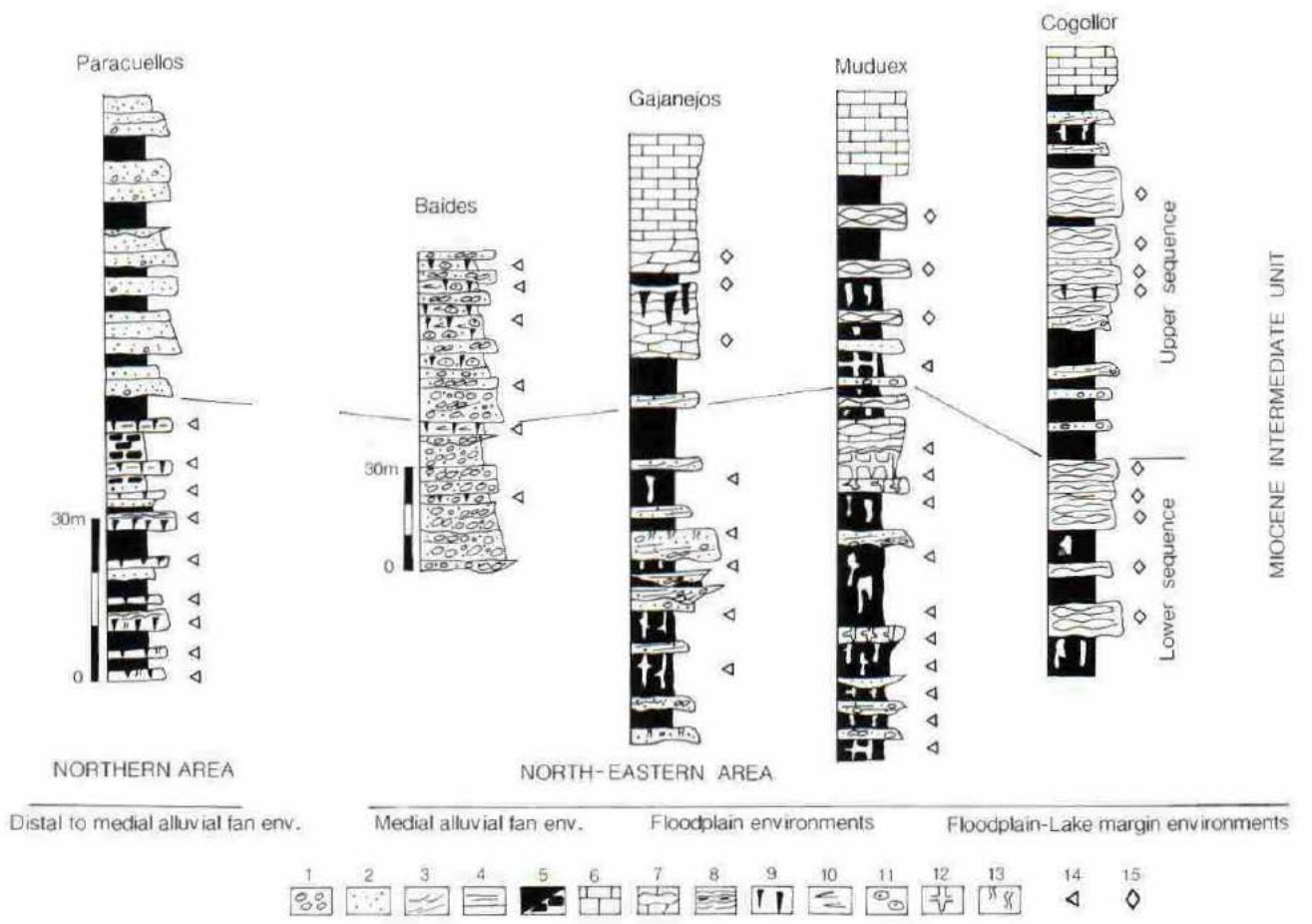

Fig. 4. Sedimentary logs of the lntermed iate Unit showing general environmental interpretations and possible correlations: 1 =conglomerate s, $2=$ sandstones, 3=crossstratification (plana $\mathrm{r} \&$ Lrough), 4= planar lamination, $5=$ clays including sepiolite, $6=$ massive (lacustrine) limestones, $7=$ nodular and mottled limestones, $8=$ platy structure, $9=$ prismatic structure, $\mathrm{IO}=$ desiccation cracks, $11=$ coated sands, 12= red monled clays \& maris, 13= biotu rbation, 14=calcrete-dolocrete, 15= palustrine limestone. The scale for Gajanejos, Muduex and Cogollor is the same as for the Baides section.

They were sourced from granitic and high-grade metamorphic rocks of the Central System. Severa! reverse fault systems defined the boundary between the source areas and the basin (Calvo et al., 1989). Well-developed alluvial fans spread from these faultbounded uplands for more than $30 \mathrm{~km}$ into the basin. Allhough the fan systems have not been studied in detail, they a redominated by arkosicdepositsshowing a typical decrease in grain size towards more dista 1 areas, ranging from granitoid and quartz bouJders and pebbles at the apices, to coarse arkosic sands interbedded with silty clays in medial fan scttings (Fig. 3a). The more proximal facies are dominated by mass Aow deposits (Alonso et al., 1986; l.G.M.E., 1989), extending, surprisingly, for many kilometres from the mountain front. Distal facies are welJ represented in the Paracuellos de Jarama area (Figs 1, 3 \& 4) where the lowest part of the seq uence comprises brown clays (with trioctahedral and dioctahedral smectites and sepiolite), calcrete beds (locally silicified) and fine arkosic sands (Alonso et al., 1986). This sequence grades laterally into lake margin deposits (Calvo et al., 1989), here composed of green Mg-smectite-rich clays, palustrine nodular doloslones and, locally, sepioli te beds. However, coarse arkosic sands in the middle part of the Paracuellos sequence represent a phase of fan progradation (Figs $2 b$ \& 4). In contrast to the north-eastern arca, no Auv ial deposits have been recognized betwccn the alluvial fan dcposits and the lacustrine sequences. Calcretes apparently formed on a narrow fan fringe, about 1-1.5 km wide, between the fan and the nearby lake margin (Calvo e1 al., 1989).

ln general, the proximal fan deposits are much 
more prominent than in the north-east, particularly near the faulled margin with the Central System. These proxim al deposits Jack calcretes while the interbedded clays contain ilfüe and dioctahedral smectites.

The general climate of the time was probably semiarid or arid. In the lake deposits there is evidence of low lake levels, desiccation and moderately alkaline waters (Calvo et al., 1989). The dominance of debris flow deposits in the fan sequences also supports the idea of low surface runoff with high sediment to water ratios.

\section{Northern-eastern region}

The architecture of the Miocene deposits along the north-east em margin of the basin is rather different (Alonso-Zarza, 1989) (Fig. 3b). Small alluvial fans, which extended a maximum distance of $10 \mathrm{~km}$ into the basin, were derived from the uplands of the Iberian Range and locally from the eastem part of the Central System (Fig. 1). These were topographically confined, non-entrench ed fans, which were fed mainly from carbonate and low-grade metamorphic terrains. In general, less active fault systems bounded the basins in this area (De Vicente et al., 1990).

The relief was probably lower in this area as ind icated by the fact that at present, the mountainsof the lberian ranges reach $1250 \mathrm{~m}$, compared to $2400 \mathrm{~m}$ in the Central System. The climate was also different; the associated Jake deposits in the north-easl indicate a freshwater system, with A uctuating but non-evaporitic margins (Calvo et al., 1989). This is in contras! to the saline-alkaline lake deposits of the northern area, where runoff must have been less than in the northeast.

Nearly $100 \mathrm{~m}$ of proximal and medial alluvial fan deposits crop out near the basin margins. These deposits consist of laterally extensive gravel sheets, with interbedded calcretes arranged in two finingthinning upward sequences. The coarseconglomerates grade to red mudstones with interbedded sand and gravel-fi.Ued channels. Thesefacies form the distal fan deposits and are crudely similar to the fluvial deposits formed on wide floodplains. Within the Intermediate Unit are two depositional sequences (Fig. 2b), each quite different in style to those seen in the nortbern area (Fig. 2). Both of these sedimentary sequences show clastic deposits at the base and lacustrinepal ustrine limestones, with a freshwater biota, at the top. The Interrnediate $U$ nit in these areas can reach $200 \mathrm{~m}$ in thickness. The clays in allu vial, fluvial and lacustrine deposits are mainly illitic (Calvo et al., 1989).

The north-eastern area is distinctly differen t from the northern area in several regards. The allu vial fans in the north ex.tended much further downslope tha $\mathrm{n}$ those in the north-east. The latter fans occupied a small area, show more marked proximal-distal trends and were dominated by stream processes and not by debris Aows (Alonso Zarza et al., 1992).

In summary, the two areas clearly differed in source area geology, tectonics, rel ief and climate (and presumably sediment supply). Not unsurprisingly, the types of palaeosols to be found also differ and these differences reftect the contrasting geological and geomorphological settings.

\section{PALAEOSOLS IN THE MADRID .BASIN}

\section{PaJaeosols in the northern area}

Two palaeosol types can be recognized in the northern area : (i) reddened clays associated with alluvial fans, and (ii) calcretes associated with distal, sand-grade deposits and lacustrine clays. The former occur on the tops of arkosic sands, deposited in the media! fan deposits, and consist simply of reddened clays wh.ich show desiccation cracks and minor manganese oxide staining. These palaeosols, classified as entisols (Soil Survey Staff, 1975), are laterally very extensive, traceable for hundreds of metres and have an average thickness of about $0.5 \mathrm{~m}$.

The calcretes are best developed at Paracuellos (3०31'46* $\mathrm{W}, 40^{\circ} 28^{\prime} 50 \mathrm{H} \mathrm{N}$ ), in the lower part of the Intermediate Unit (Fig. 4), where there is $10 \mathrm{~m}$ of stacked calcretes. Those in the lower part of the sequence (Figs $5 \& 6$, Paracuellos A) developed on bioturbated and rooted clays formed of smectites (tri- and dioctahedral), and minor i!Jite and analcirne.The individual, marly carbonate profiles average $1.2 \mathrm{~m}$ in thickness and are mainly dolomite.They consist of a lower prismatic or nodular horizon, $0 \cdot 2-0.8 \mathrm{~m}$ thick, and an upper platy horizon u p to $0.4 \mathrm{~m}$ thick. The platy horizon is not always present. These carbonates \{dolocretes in the sense of Netterberg, 1980) contain typical calcrete textures such as i rregular spar-filled cracks (including circumgran ular cracks), floating detrital grains, dense crystalline matrices and etched silicate grains (Alonso et al., 1986). The platy horizons have a distinctive microfabric with thin contorted dolomicrite veins (up to $100 \mu \mathrm{m}$ wide), coated by fine to medium crystalline 


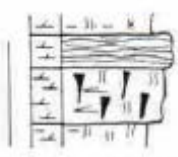

Paracuellos A
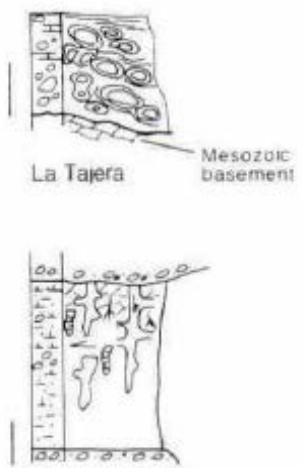

Gajanexs

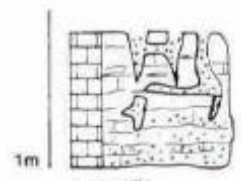

Argecill:

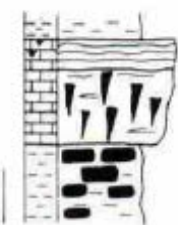

Paracuellos $B$

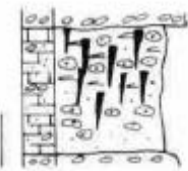

Bandes

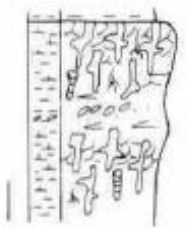

Muduex A

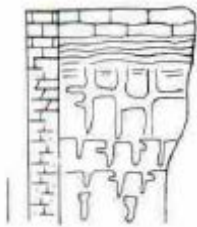

Muduex $B$

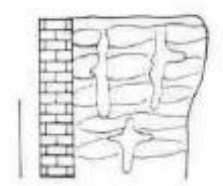

Cogolor

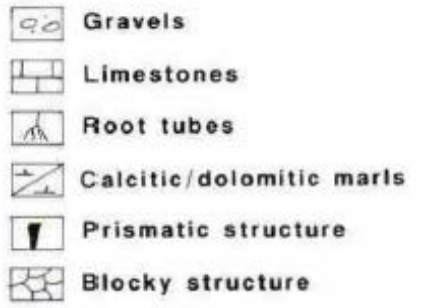

Fig. 5. Palaeosol profiles for complete caption see Fig. 4.

dolomite cernent, separating areas of locally strongly orientated clays. Rhizocretions, fungal carbonates and faecal pellets are absent. The carbonate units correspond to maturity stages 2-3 of Machette's (1985) classification.

Towards the top of this lower sequence are more mature (stage 4) calcrete profiles (Figs 4 \& 5) up to $2 \mathrm{~m}$ thick, interbedded with brown clays and fine arkosic beds (Paracuellos B). These profiles, with a higher carbonate content than those below , are formed of calcite not dolomite. The clays consist of dioctahedral smectites, with minor ifüte and kaolinite. Sepiolite is commonly found with these calcretes, and also in the underlying clays (Calvo et al., 1986). The profiles exhibit two part s, like the dolomitic ones below. The lower horizons are strongly prismatic (Fig. 5), with 

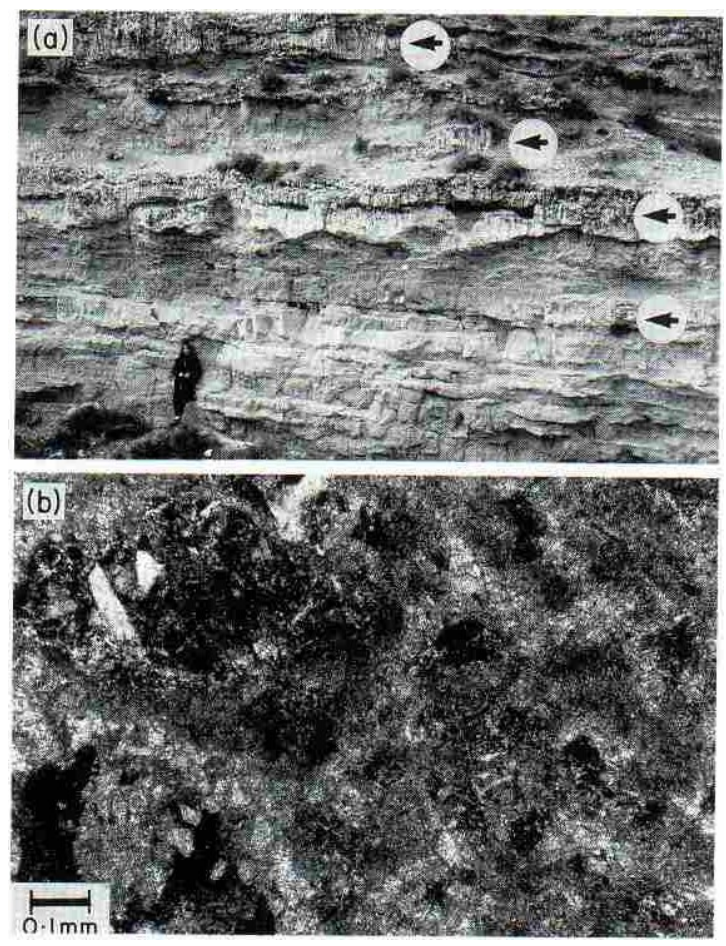

Fig. 6. (a) Mature calcrete profiles, ParacuelJos. Carbonate horizons are arrowed. Figure in lower left corner for scale.

(b) Photomicrograph of calcrete from ParacuelJos section showing irregular micritic zones forming a network, separated by patches of microspar.

individu al prisms u p to $0.5 \mathrm{~m}$ long and $50-100 \mathrm{~mm}$ wide. The $\mathrm{m}$ icrofabric consists of dense micrites with minor irregular fractures and small paLches of relict clays. The overlying platy units consist of a distincti ve reticulate pattern of micrite and microspar with intervening millimetre-scale patchesof clay (Fig. 6b). The calcretes are commonly sil icified with microquartz-filled veins. The only clay in the u pper, platy parts of these calcretes is sepioLite, suggesting a probable pedogenic origin (Calvo et al., 1986).

The calcretes are much more laterally extensive (traceable for up to $1.5 \mathrm{~km}$ ) than the dolocretes, which can be traced laterally for only a few hundred metres.

Palaeosols in the north-eastern area

Palaeosols in this part of the basin developed in a variety of environmental settings including alluvial fan, floodplain and palustrine environments.

\section{Proximalfan and colluvial deposits}

Palaeosols in the most proximal parts of this depositional system occur on coarse, mainly carbonate, gravels. These gravels were deposited in the proximal areas of alluvial fans and as screes (colluvium), resting di rectly on Mesozoic carbonates (Alonso Zarza et al., 1990). The most mature palaeosols (stages 4-5 of Machette's classification) are located on colluvium and small fans in the La Tajera area $\left(2^{\circ} 27 ' 30 \mathrm{H} \mathrm{W}\right.$, $40^{\circ} 49^{\prime} 50 \mathrm{H} \mathrm{N}$ ) (Alonso Zarza et al., 1990). The lateral extent of these calcretes is only a few hundred metres. They developed on coarse, very poorly sorted, matrixsupported carbonate conglomero-breccias in which the clasts range from $0.7 \mathrm{~m}$ in diameter lo sand sized (Fig.5). Here the profiles vary in thickness from 0-4 to 3 $\mathrm{m}$, and the thicker ones reach a maturity of Macbette'sstage 5. The thicker profileshave a twofold division with a lower horizon with coated clasts and an upper oneof sheet-like laminar calcrete up to O·I m thick. The coatings on the clasts are locally up to $40 \mathrm{~mm}$ thick, and are continuousaround the clasts but show microstalactitic thickenings. The submillimet re to millimetre thick laminae, present botb coatiog the clasts and within the laminar horizons, consist of dense micrite-microspar layers. The th icker larninae consist of fine to coarse sand-grade peloids and coated grains (Fig.7), cemented by spar and rnicrospar. Detrital grains were incorporated into laminae.

The coatings show none of the biogenic fabrics typical of some calcretes sucb as m icritic outgrowths or needle-fibre calcite (Wright, 1989). The peloids are irregular in shape and poorly sorted, unlike faecal pellets in calcretes (Wright, 1983; Jones \& Squair, L 989). Peloids and coated grains are common in calcretes sbowing large void spaces (sucbas those

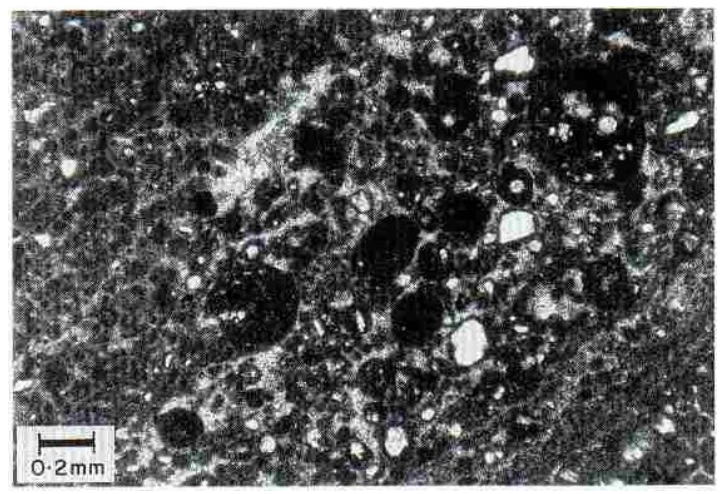

Fig. 7. Photomicrograph of peloidaJ fabrics of calcretes developed on colluvial deposits. norlh-eastern area. 
developed on coarse-grained deposits or highly fractured mature calcretes: Hay \& Wiggins, 1980). The peloids are disorthic to allorthic features (in the sense of Wieder \& Yaalon, 1974). They have been translocated in the soi! i n many cases, and concentrated in the larger pore spaces.

Carbonate-coated clasts are a common feature of soils developed on Quaternary alluvial fans but there are few descriptions of their micromorphology . Fibrous calcite coatings, of the types noted by Chadwick el al. (1989), Blank \& Fosberg (1990) and Reams ( 1990) from various carbonate-coated clasts in soils from the United States, were absent.

The laminar calcretes capping the profiles show dense micrite and peloid-rich laminae, appear to be abiogenic in origin and lack the typical features seen in microbial or rhizolite laminar calcretes (cf. Wright elal., 1988; Wright, 1989).

In the proximal areas of the fans, soils developed on coarse conglomerates but they are not common and are spatially restricted. They correspond to stage 1-2 profiles of Machette ( 1985), and consist of 2-3 mm discontinuou s carbonate coatings on clasts, thinner than those in the La Tajera colluvium. However, petrographically they are similar to the coatings in the scree deposits of La Tajera.

\section{Medial fan areas}

Near the village of Baides $\left(2^{\circ} 45^{\prime} 11 \mathrm{HW}, 41^{\circ} 00^{\prime} 40^{\prime \prime} \mathrm{N}\right)$ a discrete mappable fan, the Baides Fan, was developed. Its medial fan facies, consisti ng of more than $100 \mathrm{~m}$ of stacked coarse grave] sheets with interbedded coarse sandstones (Figs 3b \& 4), includes several calcretes (Alonso Zarza el al., 1992). The calcrete profiles (Fig. 5) average $2 \mathrm{~m}$ in thickness and are discontinuous, beiog tracea ble for about 200- 500 $\mathrm{m}$ along depositional strike. The calcrete profiles, which are at stage 3 maturity of Machette's (1985) classification, show a prismatic structure (Fig. 8a). Thin micritic coatings around the sand grains are the most typical petrographic features (Fig. 8b), and small carbonate nodules, rhizocretions and fine calcite sparfilled cracks are also present.

\section{Distal areas andjloodplains}

Palaeosols in the distal fan facies are similar to those recognized in floodplain sequences. Two major sections, Gajanejos and Muduex, illustrate the variability in palaeosol development seen in these fluvial deposits. These two sections are $5 \mathrm{~km}$ apart and differ in the volume and style of associated channel deposits.
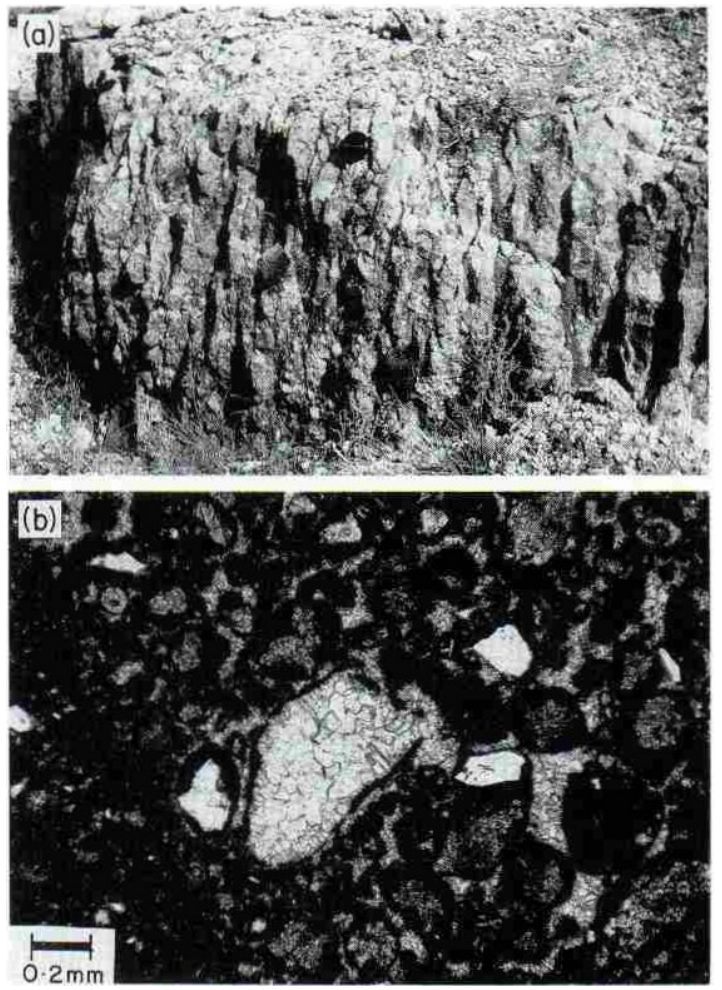

Fig. 8.(a) Prismatic calcrete, Baides media.! fan facies. Lens cap for scalc. (b) Photomicrograph of micritic coated grains and micritic-walled tubule (centre), from calcretes shown in (a).

In the Gajanejos area $\left(2^{\circ} 56^{\prime} 06 \mathrm{H} \mathrm{W}, 40^{\circ} 51^{\prime} 08 \mathrm{n} N\right)$, the sequence contains a number of large channel sandstones up to $8 \mathrm{~m}$ thick (Fig. 4). The area appears to have been within a major channel belt and the associated floodplain deposits consist of coarse- to fine-grade sands, silts and clays. IndividuaJ units bearing pedogenic features can be up to $3 \mathrm{~m}$ thick. The red clays in these palaeosols are predominantly formed of illite and minor chlorite (Jess than 5\%). Carbonate occurs as i rregular, centimetre-sized, nodules and is commonly surrounded by green, vertically elonga te, centi metre-sized mottles. The silts and clays have a subangular to blocky structure. Carbonate content, as well as mottling intensity, increase lowards the top of each profile (Fig. 5) and root bioturbation effects are commonly seen. The maturity of these soils is up lo stage 2 in the sense of Machette (1985).

In the Muduex area ( $\left.2^{\prime \prime} 57^{\prime} 02^{\prime \prime} \mathrm{W}, 40^{\circ} 50^{\prime} 12^{\prime \prime} \mathrm{N}\right)$ the lower part of the lntermediate Unit exhibits over $120 \mathrm{~m}$ of pedogenically modified floodplain deposits (Figs 3b \& 4). Thick channel deposits are absent, 


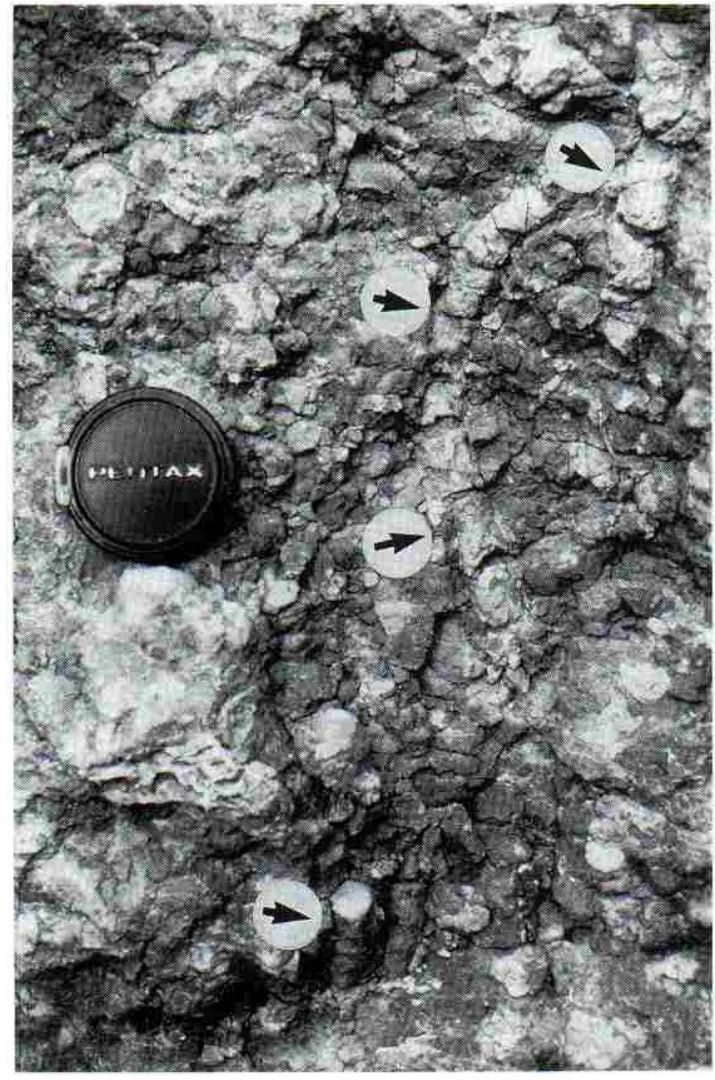

Fig. 9. Elongate carbonate nodules (arrowed) from a floodplain palaeosol, Muduex area.

small erosi vely based, fining upwards, sheet-like channels occur filled by imbricated gravels and planar cross-stratified sandstones. The associated floodplain deposits a.re liner grained than at Gajanejos and consist of silts and clays. The tops of the sandstones were pedogenically mod ified, and most of the flood- plain deposits show evidence of modification incl ud- ing abundanl, centimetre-sized carbonate nodules, root traces and burrow mottl ing (Muduex A, Fig. 5). Carbonate concretions commonly foUnow roots or burrows (Fig. 9). Reduced (green) mottling is partic- ula rly common around these roots, burrows and elongate carbonate nodules, forming 'drab-haloes' in the sense of Retallack ( 1990). These haloes probably represent areas of reduction associated with organic matter decomposition as the regional water table rose during floodplain accretion (accumulative hydromor- phy phase of Brown \& K raus, 1987). The maturity stages seen in these carbonate profiles increases but progressively up-sequence (Figs $4 \& 5$, Muduex A to B) from stage 3 to 4 of Machette (1985).

The Muduex B profile shown in Fig. 5 is located in the middle part of the lower sequence.It can be traced lateraUy for several kilometres and, towards the east (towards the Gajanejos area), its maturity progressively decreases until, close to the Gajanejos section shown in Fig. 4, it passes into sands and silts lacking obvious soi!features. In the Muduex area this profile isdeveloped on red si lts and clays, the latter cornposed mainly of illites and minor interstratified illitesmectite. The profile contains some centimetre-thick grave! sheets, suggesting it is cumulative. The lowest part of the profile is a red silt with small, centimetresized carbonate nodules, passing progressively upwards i nto a continuous massive carbonate horizon. This upper unit locally contains ostracod valves, suggesting a possible palustrine origin .

\section{Palustrine association}

Palustrine carbonates are developed mainly at the top of each of the lower and upper sequences of the Intermediate Unit, and represent deposition in shallow lakes on the floodplains (Calvo et al., 1989). Their wide extent and lack of interbedded clastic material suggests they developed when alluvial deposition from the fans or fluvial systems was reduced. Profiles analysed in this setting lie within the upper part of the Intermediate Unit. Lacustrine areas reached their maximum extent in the north-eastern area at this level. Thus, the deposits analysed here are younger (late Aragonian to early Vallesian age) than the palaeosols previously descri bed (middle to late Ara- gonian) (Fig. 2).

In these settings the palaeosols developed on carbonate (limestone) su bstrates. It appears that soi! processes did not contri bute sign ificantly to the accumulation of carbonate but modified the previous ly deposited palustrine carbonates (e.g. see also Platt, 1989). Two sections have been studied in detail: Cogollor and Argecilla (Figs 3 \& 4). In general terms the Cogollor section is associated with alluvial facies while that at ArgeciUa is, stratigraphicaUy, more closely related to lacustri ne deposits (Alonso Zarza, 1989). In the Cogollor area palustrine deposits are represented by more than $20 \mathrm{~m}$ of mottled (yellow to brown) bioclastic limestoae beds averaging $2 \mathrm{~m}$ in thickness (Fig. 5). The limestone beds are usually nodular and, in th.in section, show strongly developed microfractures (Fig. 10). Root traces are common, as are ostracod and charophyte debris. Desiccation 


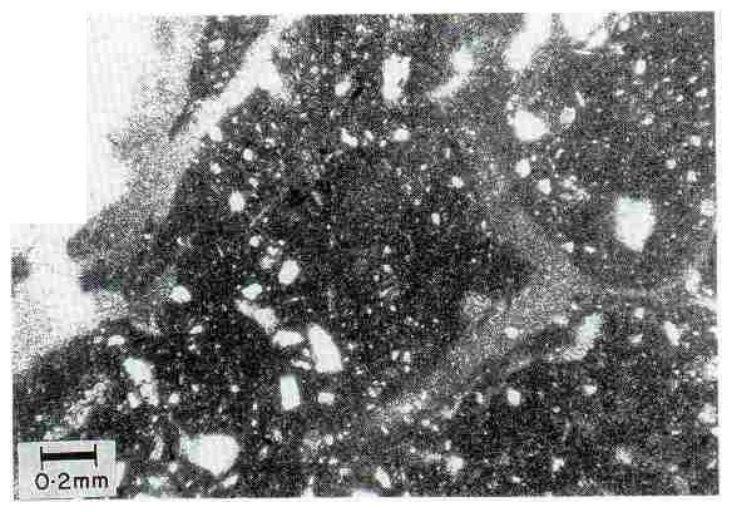

Fig. 10. Photomicrograph showing micritic cakrete limestonewith microspar and spar-filled microfractures, Cogollor section .

features increase in abundance towards the top of many of the beds. Centimetre-sized cavities in the Limestonesare fiJled geopetally, with laminated vadose silts at the bottom and calcite spar cernent at the top. Manganese oxide coatings are associated with the cavities. More extensive, connected cavities and solutional depressions (microkarst of Freytet \& Plaziat, 1982) are rare.

The Argecilla sequence is different from that at Cogollor, showing well-developed pseudo-microka rst (Fig. 5). The thickness of the individual profiles averages $0.7 \mathrm{~m}$. The lower parts of each profile are formed by graded units of gravel-sized carbonate i ntraclasts cemented by calcite spar, commonly show- i ng micritic coatings. The middle part of each unit shows a micritic matrix with desiccation cracks but fewer intraclasts. At the top of each unit,large vertical and horizontal fractures eut the micritic J imestone and are filled by intraclasts of sand to grave!grade. Open, vertical cavities, up to $0.7 \mathrm{~m}$ long (Fig. 11a)

occur which may represent root moulds. These are particularly common in limestones rich in lacustrine gastropods. Colour mottling is not well developed, but the most striking feature of these limestones are large (cm-dm), irregular cavi ties filled by peloids and Jarger intraclasts. The origin of the grains is seen in the surroundin g bioclastic lime mudstones where desiccation has resulted in the formation of circumgranular cracking and peloids by 'grainification' (Mazzullo \& Birdwell, 1989; Wright, 1990). Sorne of the peloids also represen $t$ small calcrete nodules (Fig. 11b). These cavities, and the peloids, correspond to the pseudomicrokarst and 'secondary pedogenetic grainstones' respectively of Freytet \& Plaziat ( 1982), commonly seen in many ancient palustrine limestone sequences.

\section{PALAEOSOL -PALAEOLANDSCAPE RELATIONSHIPS}

It is clear that there are varied sets of palaeosols in the two areas, with marked differences, not only between the northem and north-eastem areas, but also within the north-eastern area alone. This is particularly true wi th regard to the maturities of the profiles described. Before offering possible explanations for these differences, some of the con trois on soil development on alluvial fans and floodplains are briefly reviewed .

\section{Alluvial fans}

Soil-landscape relationships on alluvial fans are very complex, reflecting spatial and temporal variations in the geomorphological stability of fan surfaces. Stable surfaces. undergoing neither deposition nor erosion, undergo pedogenesis, and such surfaces develop on fans because of a number of factors. $1 \mathrm{n}$ non-entrenched fans, where the surface aggrades over a large part of the fan there is, typically, a contrast in depositional
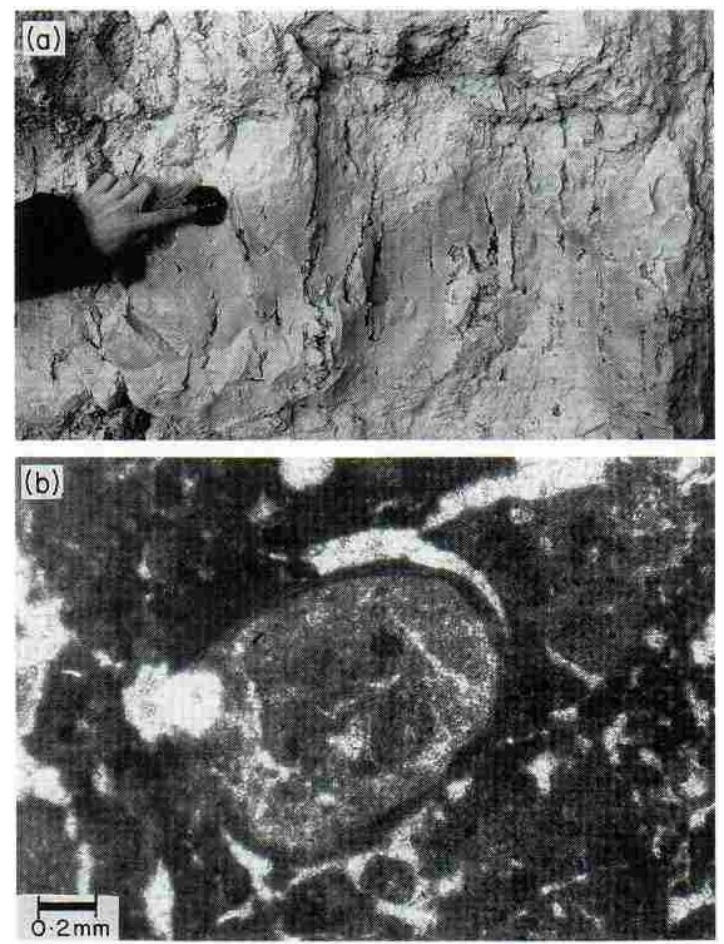

Fig. li. (a) Palustrine limestonc, Argecilla, showing prom inent vertical cavities, interpreted as probable root moulds. Lens cap for scale. (b) Circum-granular spar-filled fractures in palu strine limestone, Argecilla. 


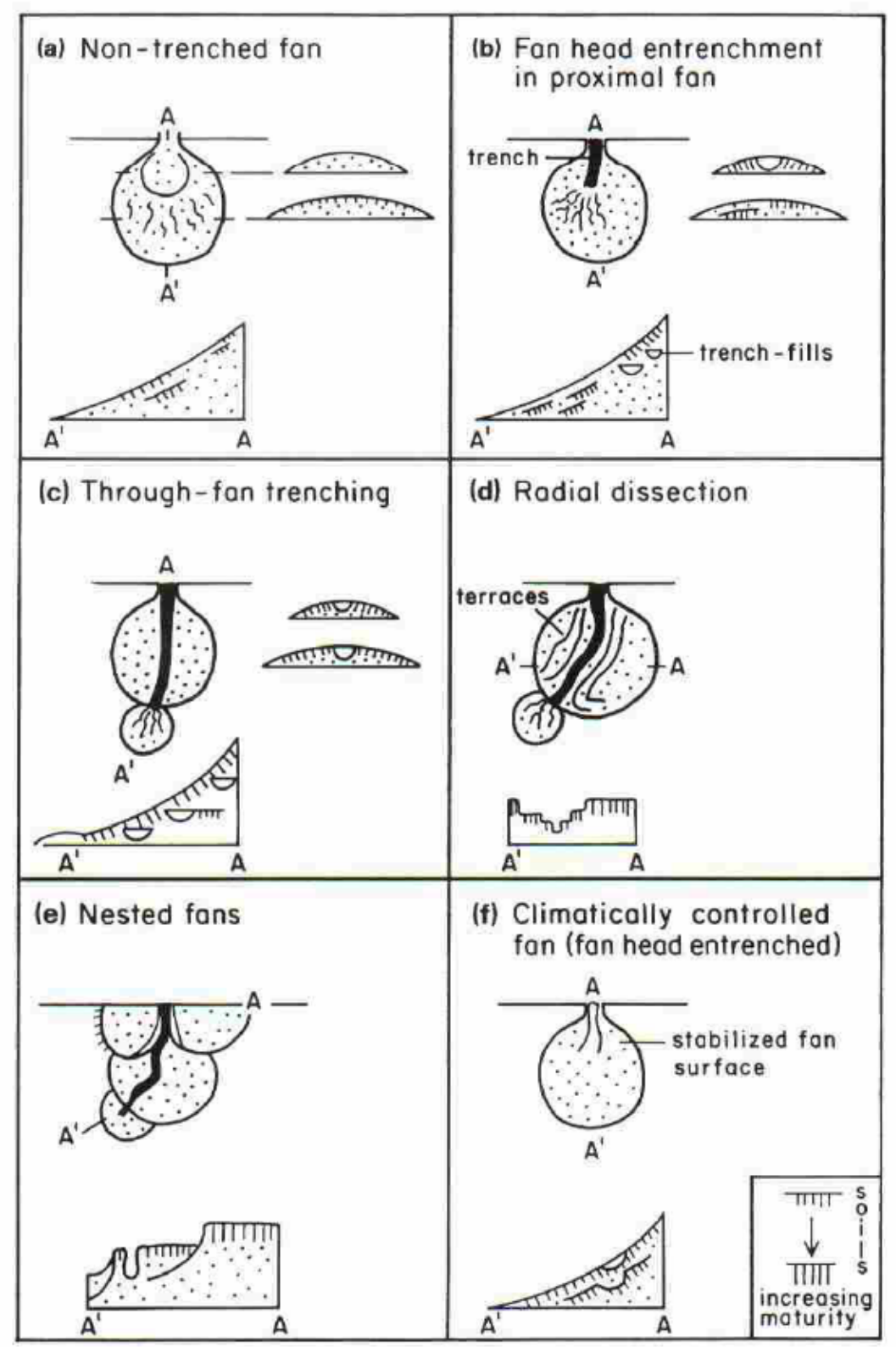

Fig. 12. Schematic pedostratigraphic models for alluvial fans (see text), modified from Wright (1991).

rate between proximal and more distal areas. The proximal areas have higher deposition rates and will have Jess developed soils than more distal areas receiving Jess sediment (McCraw, 1968) (Fig. 12a). This is a pedofacies relationship in the sense of Bown \& Kraus (J987). In entrenched fans, the extent of the trench system affects soil development quite radically (McCraw, 1968; W right \& Alonso Zarza, 1990).If the trench is restricted to the upper part of the fan, the areas adjacent to this channel receive little or no sediment, and the surface is subject lo soi! formation (Fig. 12b). As a consequence of trench switching, areas below the intersection points will experience alternating periods of deposition and pedogenesis, but in general the soils in these more distal areas will be less well developed than those adjacent to the trench channel. In situations where thes tream hasentrenched the full length of the fan ('through-trenches'), pedogenesis occurs over the whole fan surface (McCraw, 1968) (Fig. 12c\}. An additional factor is distal fan 
trenching, typically associated with through-fan trenching (Harvey, 1987), where intersection point head-cuts or base- level-induced incision leads to the distal zone becoming trenched.

The fan deposits also reflect these differences in the degree of entrenchment. Non-entrenched fans consist of more sheet-like deposits with small-scale channelling, whilst entrenched fans exhibit larger channel and channel-fill features, with inset stratigraphies (Harvey, 1989).

Many fans are not just entrenched but are also dissected, either radially (Fig. I 2d) or to produce nested surfaces (Fig. 12e). In such cases the fan has a complex topography with a variety of surfaces of diiferent ages. The fan deposits also reflect this complexity with major channel/valley features and fills.

Geomorphological controls, as well as climate and tectonics, control the degree of fan entrenchment and dissection (Lecce, 1990). However, on Quaternary fans climate controls major phases of surface stability and pedogenesis, by switching off the whole depositional system (Talbot \& Williams, 1979; Gile et al., 1981; French, 1987; Harvey, 1990; Wright \& Alonso Zarza, 1990) (Fig. 12f).

Not only is the distribution of soi!surfaces on fans very complex, but local differences in fan behaviou $\mathrm{r}$ make inter-regional comparison of soi!stratigraphies very difficult. Areas relatively close to one another, with different geology, relief and microclimate, may not only display different depositional styles, but may also respond in different ways to changes in climate. For example, a change to a regime with increased effective preci pitation can causesomeareas to increase their sedirnent yield, increasing fan deposition, whilst nearby fans in a different rnicroclirnate, already at their peak sedirnent yield, rnay respond by an increase in the vegetation cover, causing fan stabilization (French, 1987). Ail these factors must be borne in mind when interpreting soil-land scape relationships in an area like the Madrid Basin, where marked regional va riations in geology, relief and climate occurred.

\section{Floodplain systems}

Soil-land scape relationships in floodplain settings have been extensively documented from present-day systems and have also been interpreted in ancient sequences using palaeosols. The two main types of relationships are those related to catenas and to differential sedimentation rates (pedofacies). Topo- graphie differences, alfecting soi! d.rainage, result in different soil types on a floodplain, caused by more and less poorly d rained areas (Gerrard, 1981 ; Wrigh t, 1991). Pedofacies relationships are seen where the maturity of a soil or palaeosol increases across a floodplain in response to the decreasingsedimen tation rate away from the channel belt (Bown \& Kraus, 1987). Near the channel belt higher rates of sedimentation result in numerous, stacked profiles with Jess well-developed soils, whilst distant from the channel the soils receive much lower increments of sediment and are more mature (Kraus, 1991). This simple pattern is typically obscured in most floodplains where terracing disrupts the trend, with surfaces often in staircases, creating a complex set of soils of varied ages, typically in close vertical proximity to one another (Wright, 1991).

With these general principles in mind the differ- ences in soil maturity and soi!type in the Madrid Basin can be related to lheirgeomorphological settings (shown schematically on Fig. 13).

Palaeosol relationships in the northem area

Alluvial fan seuings

Debris fiow deposils dominate these fans and extend considerable distances from the mountain front, suggesting high sediment to runotf ratios. High rates of sediment supply probably reflected conti nuing tectonic activity. The predominance of debris flow deposits also probably reflects high relief in the drainage basi n, as is commonly seen in Quaternary fans(Harvey, 1990). Theabsenceof extensiveoutcrops in the proximal fan depositsdoes not allow assessment of whether or not they were entrenched, but matu re palaeosols were apparently absent (I.G.M.E., 1991).

Weakly developed palaeosols frorn the medial fan areas simply show reddening. The absence here of well-developed palaeosols suggests rapid fan aggradation without the development of long-terrn stable surfaces. Never theless, the weakly developed palaeosols are laterally extensive, ind icating that short-term stability prevailed over large areas. Short period s of stability could have occurred on abandoned fan segments; certainly the lack of deep cut-and-fill sequences observed in the field argues against entrenchment and dissection in such areas. The high aggradation ra les and Jack of extensive entrenchment suggest that the fans were never aged to a point where entrenchment occu rred (cf. Harvey, 1989). 


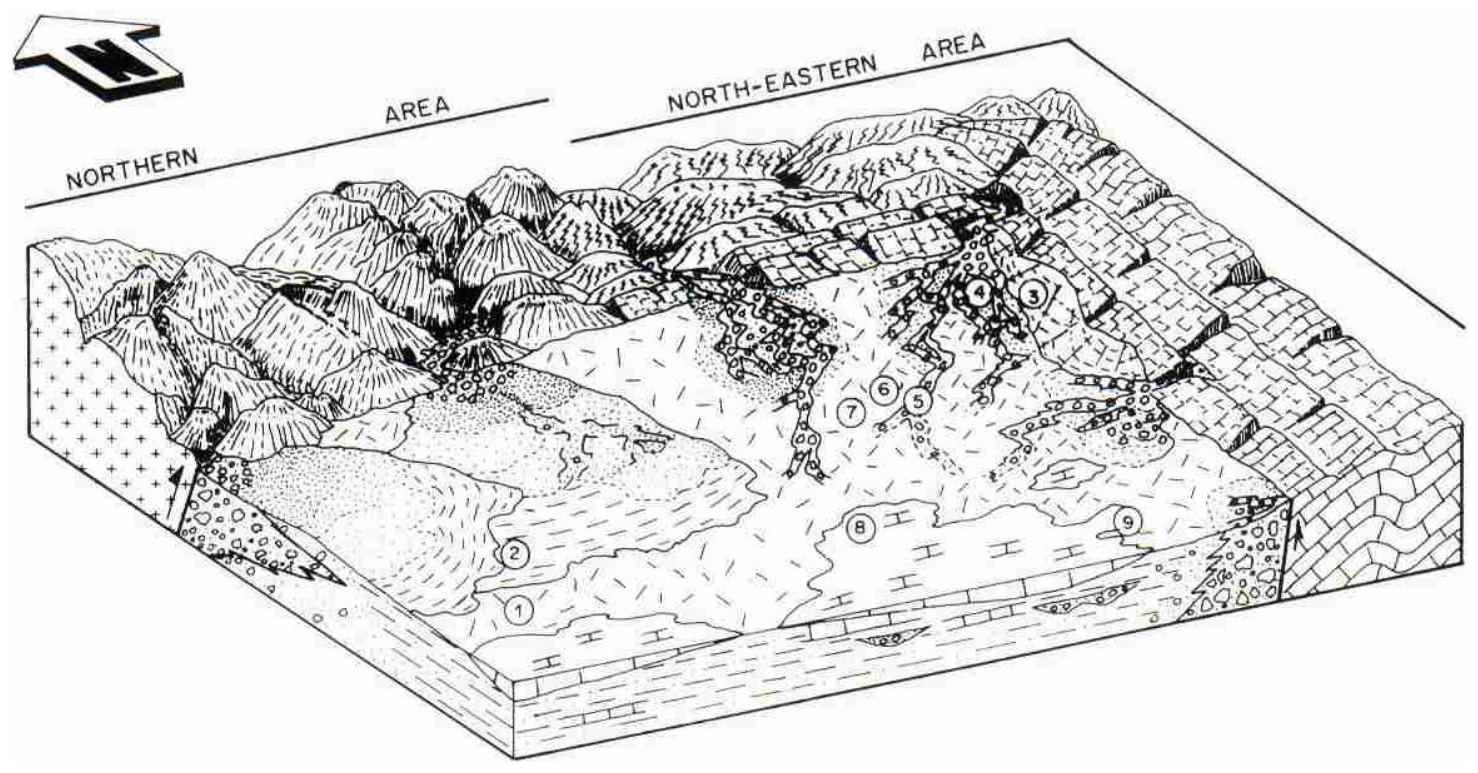

Fig. 13. Tdealized reconstruction of middle Miocene landscapes of part of the Madrid Basin. Num hers refer to palaeosol profiles in Fig.5: 1 = Paracuellos A, 2 =Paracuellos B, 3 = La Tajera, 4 = Baides, 5 = Gajanejos, 6= Muduex A, 7= Muduex B, 8= Argecilla, 9=Cogollor. For key see Fig. 1 and Fig. 5.

\section{Lake margin settings}

Ttie mature palaeosol $s$ in the Paracuellos area may have formed in interfan or extreme fan toe settings, influenced by the nearby Jake but experiencing low aggradation rates for long periods. The proximity to a fluctuating endorheic Jake system would have resulted in frequent changes in the local base level. Drops in lake level would have caused trenching of the distal fans, creating more stable surfaces for soil develop- ment. However, there is no evidence of such dissection in the mid fan deposits suggesting that, if such falls occurred, they were very small. It seems likely that the mature calcretes developed during small-scale falis in Jake level, which exposed large areas of the lowgradient lake margin and caused local stabilization of the most distal fan areas. Miner falls in Jake levels are common i.n endorheic lakes and may reflect local and mi nor changes in the prec ipitation/runoff/evaporation budget, not great enough to have affected the adjacent fans themsel ves. In ail lhese points, the limited ou tcrop of the northern fan deposits is a crucial factor to consider.

The stratigraphically lowest palaeosols contain dolocrete horizons lacking sepiolite but with analcime. An upward change from dolocrete tocalcretecoincides with the coarsening u pwards to moredistal fan arkosic sands. The clays on which the dolocretes developed are similar to clays in the adjacent Jake deposils, which have a high percentageof trioctahedral srnectite (Calvo et al., 1989). These clays were the probable source of $\mathrm{Mg}$ for dolomite formation. In contrast, the calcretes developed on clays mainly composed of dioctahedral smectite and illite, having a lower $\mathrm{Mg}$ content. Sepiolile is concentrated only i $\mathrm{n}$ the most carbona te-rich layers in the calcretes, a feature also noted by Netterberg (1969) and Watts (1980) from Quaternary calcretes in southern Africa. To explain this inverse relationship between sepiolite concentra- tion and the $\mathrm{Mg}$ content of the associated pedogenic carbonates, Watts ( 1980) suggested that Mg was released from high-Mg calcites in the soil carbonate following inversion to low-Mg calcite; the $\mathrm{Mg}$ enriched the soil waters and led to sepiolite neoformation .Alternati vely, the preferential removal of $\mathrm{Ca} \mathrm{CO}_{3}$ as low-Mg calcite might have led to locally high $\mathrm{Mg}$ levels in concentrated soi) solutions(Calvo er al., 1986; McGrath \& Hawley, 1987). The occurrence of pedogenic sepiolite in the calcretes i.n lhis area and not in the north-eastem area is significant, and by analogy with Quaternary calcretes (McG rath \& $\mathrm{H}$ awley, 1987) suggests a difference in microclimate with the northern area being more arid than the north- 
east. However, the availability of a source of $\mathrm{Mg}$ is a critical factor in influencing the distribulion of sepiolite.

The calcrete and dolocrete profües, while most closely resembling the discrete profiles found in pedogenic calcretes/dolocretes, may have been influenced by groundwaters (e.g. see examples discussed by Watts, 1980). No direct evidence has been noted for this, but analcime, which occurs in the calcretes, is commonly associated with high or perched water tables and high $\mathrm{Na} \mathrm{CO}_{3}$ concentrations (Nettleton \& Peterson, 1983).

The availability of $\mathrm{CaCO}_{3}$ may also have affected the distri bution of calcretes in this a.rea. The Jack of carbonate in the fan palaeosols has been interpreted as reflecting high aggradation rates. However, in Quaternary fan sequencesthe distribution of calcretes is closely related to the nature of the substrate and proximity to playas (Lattman , 1973; Gile, 1977). Soils forming on Ca-poor substratesdevelop calcic horizons much more slowly (or not at ail) compared to those with an abundant supply of Ca from 1 imestone or dolom ite clasts. Local supplies of $\mathrm{Ca}$ are usually not the main source of Ca in such soils, which cornes from aeolian sources (Machette, 1985), but the local supply enhances the rate of accumulation. The Paracuellos calcretes and dolocretes had local sources of $\mathrm{Ca}$ and $\mathrm{Mg}$ from exposed Jake carbonates, whilst the fan deposits have a low Ca or Mg content and chemical weathering of the mainly granitic clasts may have been low under the prevailing 'arid-type'climate.

\section{Palaeosol relatiooships in the north-eastern area}

Exposure is much better in this area, where the depositional style and range of palaeosols is quite different, reflecting the differentgeology, relief,tectonics and climate.

\section{Colluvial and fan seuings}

The calcretes which developed on the colluvial deposits are well developed and indicate stable screes most probably stabilized by vegetation. Alonso-Zarza ( 1989) found no evidence of deep channelling and cutand-fill sequences in any part of the fan deposits in this area, reflecting a Jack of entrenchment or dissection. This is supported by the presence of only weakly developed palaeosols in the proxim al fans suggesting that stable surfaces were not developed . This situation is typical of the proximal parts of nonentrenched fans (McCraw, 1968; Wright \& Alonso
Zarza, 1990). The presence of more mature calcretes in the medial areas indicates more stable surfaces. On non-entrenched fans much of the sediment load is dumped near the fan apex so that areas lower down the fan experience Jess sediment input. This simple 'pedofacies' relationship is unlikely to expla in the pattern seen in these Miocene fans, for the mature medial fan calcretes probably required long periods to form, perhaps thousands or tensof thousands of years. It is unlikely that preferential deposition in the apex could have continued for this length of time for the fan profile would have become very steep in the apex region and unstable. A second explanation is that the channels on the media! fan were Jess mobile than thoseon the proximal fan,allowing interchannel areas to develop more mature soils. Crusting of the fan surface by calcretes limits lateral erosion by channels on Quaternary fans (Harvey, 1989) favouring continued soil development. In add ition, more permanent channels develop with time on Quatemary fans (Christenson \& Purcell, 1985). We therefore favour the explanation that the absence of well-developed palaeosols in the proximal fan and their presence in the medial areas refiect the different activity of distribut ary channels in the two areas. The media! fan areas had more stable channels, the degree of soit development on the fans being as mucb a function of preservation potential than of aggradation rate.

The distal fan deposits contain Jess mature calcretes which most likely reflects areas of more widespread and rapid deposition. However, the finer grain sizes of the sediments may have been an additional control because calcretes require longer period $s$ to reach the mature stages in finer su bst.rates (Gile et al., 1966).

In summary the pa1aeosol distri bution on the northeastern area fans ind icates that they were neither en trenched nor d issected. Relatively stable areas developed in the media! fan, perhaps as a consequence of the fixi ng of channels by fan crusting. There is no evidence from the palaeosols of fan-wide periods of stabili ty which might have been caused by climatic changes.

\section{Floodplain sellings}

The floodplain palaeosols exhibit lateral va nat1ons reflecting their position $\mathrm{s}$ on the floodplain relative to the main channel belt that drained the whole northeastern area . The Gajanejos area, which was proximal to the channel belt, as indicated by abundant channel deposits, has thick fiood plain deposits with weak ly developed palaeosols (Fig. 4). In more distal areas, 
such as Muduex, channel deposits are rarer and the palaeosols are betler developed. This appears to represent a simple pedofacics relationship in the sense of Bown \& Kraus ( 1987). This trend is supported by the fact that the grain size of the floodplain sediments decreases from Gajanejos to Muduex.The decreasing maturity and eventual disappearance of the palaeosol which was traced from M uduex to Gajanejos also supports this view. Calcrete maturity in the $\mathrm{M}$ uduex area i ncreases up sequence, followed by Jacustrine/ palustrine deposits. This suggests reduced sediment input and rising Jake levels, perhaps reflecting shifts to wetter conditions with increased stabilization of the fans by vegetation .

\section{Lake margin settings}

The palustrine deposits represent pond, marsh or lake margin sediments (Calvo et al., 1989), and show contrasts between the two main sections, Argecilla and Cogollor. At Cogollor, the palustrine un its occur in a floodplain sequence, where the carbonates are interbedded with clays. The presence of mollling, minor pseudo-microk arst and fracturing suggests some hydromorphism and also some short periods of exposure. These carbonates $\mathrm{m}$ ay have developed in small floodplain lakes or ponds.

The Argecilla palaeosols show extensive pseudomicrok arst development s and ped (peloid) formation, indicating a longer exposu re period, and a vegetation cover probably resulti ng in microkarst development (cf. Freytet \& Plaziat, 1982). Argecilla is more proximal to the main la ke area in the basin (Alonso Za rza, 1989) and these palustrine palaeosol profiles probably represent period s of lower lake levels exposinglake margin sediments.

\section{Comparison of palaeosol development in the two areas}

The differences in palaeosol development between these two areas reflect the interplay of several factors. The northern area, with its presumed higher topography (as today), more acti ve faulting and more arid conditions, exhibits a th icker proxirnaJ fan sequence com posed of mass flow deposits reflecting a high sediment to water ratio from a steep, mainly granitic catchrnent area.The arid climate may have favoured catastrophic fioods. These fans were neither entrenched nor dissected, resulting in a lack of mature palaeosols. The probable high aggradation rates, coupled with the arid ity and carbonate-poor substrates, resulled in a lack of calcrete development. The playa margin palaeosols exhibit dolocrele horizons reflecting their Mg-rich substrates, whilst on the Mgpoor fan fringe deposits, calcretes formed.

Incontrast, the north-east was wetter, as evidenced by permanent carbonate lakes (Calvo et al., 1989). The resultant greater runoff resultcd in fans dominated by braided stream deposits, reflecting alower sediment to water ratio. The associated calcretes (and not dolocretes) reflect both the greater availability of $\mathrm{CaCO}_{3}$, from carbona te source areas, and the lower levels of $\mathrm{Mg}$ in the substrate. The presence of floodplai n deposi ts also reflects the greater runoff in this area. Calcrete-bearing palaeosols occur in these deposits, show ing pedofacies relationships, with weakly developed profiles proximal to the channels, and more mat ure ones d istal to the main channel belt. Small carbonate lakes (or pond s) also formed on these floodplains. Soils formed on the exposed lake, marsh and pond carbonates. Such contrasts in the two fan systems within one region are not unusual (sec e.g. Harvey, 1990).

\section{CONTRASTS WITH QUATER NARY ALL UV I A L FAN SEQU ENCES}

There are striking differences between these Miocene alluvial fan sequences and those seen in Quaternary fans. Many Quaternary fans are deeply entrenched, partly or fully, and/or dissected (French, 1987). The causes of trenching are diverse (Schumm et al., 1987; French, 1987). Intrinsic factors tend to result in shortlived entrenchrnent (Harvey, 1989); extrinsically triggered entrenchment is typically more significant. Externat factors include tectonic activity (steepening the fan profile), climatic changes (leading to increases or decreases in stream power) and local changes in base level in adjacent basins caused by changed lake or sea levels.

Tectonic factorsare important in affecting the longterm development of sorne fans (Harvey, 1989, 1990), acting to create the location and space for the fan. However, other factors such as climate and source area geology can control the short-term development and stratigra phy of the fan (Harvey, 1989). Fault movement s are generally infrequent and their effects on the fans are overprinted by geomorphological and climatic factors. Indeed, even in fans where active uplift occurs in proximal areas, such as the Tapia fans of south-ea stern Spain (Harvey, 1984), the mid and distal fan areas arenot affected.Although thenorthem area was probably tectonically active during the 
middle Miocene, this need not necessarily have been an important factor controlling the morphology or stratigraphy of the fans.Climatic change isregarded as critical in controlling Quatemary fan development (Talbot \& W illi ams, 1979: G ile et al., 1981 ; Lettis, 1985 ; Dom et al., 1987: Blair et al., 1990: Harvey, 1990). Climate is a part icularly crucial influence on vegetation cover and is the main factor controlling fan stability. Quatemary climat ic changes inducing stability have resulted in surfaces (and thei $r$ associated soils) being regionally traceable (Gile et al., 1981). Asstated above, the range of maturity seen in the palaeosolson the Miocene fans argues against widespread period s of fan stabiliiy and suggests that clima tically controlled phases of fan growth and stability did not occur. Evidence for possible climatic change does corne from the associ- ated lake deposits. The small-scale interfingering, in both areas, Jake deposits and alluvial fan or floodplain un i ts (Calvo et al., 1989) is clear evidence of both minor and major changes in the Jake level. These did not appa rently affect the fan systems as a reult of incision due lo a change in the base level. Two largerscale lake transgressions, recorded in the 1ntermediate Unit of the north-east area, reflect more significant climatic changes. However, no major palaeosols have been found which might correlate with these events. This could be explained by the fact that the fans did not di rectly feed inlo the lakes (Alonso Zarza et al. 1992).

In summary, the major differences between these Miocene fan sequences and many Quatemary examples is the relati vely regular fan growth exhibited throughout the middle $\mathrm{M}$ iocene in both regions of the Madrid Basin. Major climatically cont rolled alternations of aggradation, and stability/degradation, which have characterized Quaternary fan growth are not seen in the Miocene fan sequences. Changes in lake levelsin the region do not seem to have been associated wi th changes in runoff sufficiently large lo cause fanwide shifts in stability.

\section{CONCL US IONS}

The Miocene alluvial and lacustrine deposits of the Madrid Basin contain a variety of palaeosols developed in a range of landscapes.

The northern part of the basi $\mathrm{n}$ had higher relief and was arid and tectonica11yacti ve.Soilson the fans were wea kly developed, reflecting aggrad ing fan surfaces. Local sources strongly inftuenced the composition of the pedogeni c carbonates which formed in the more distal settings. Calcretes formed on Mg-poor fan sediments whilst dolocretes developed on Mg-rich Jake clay. In contrast, the north-eastern part of the basin had lower relief, was Jess arid and tectonically active and was fed by streamssourced by carbonate terrains.The fans were characterized by stream flood deposition, and extensive flood plains; freshwater lakes developed down-basin. Calcretes developed on the fans, perhaps part ly reAecting the grea ter availability of carbonate. $U$ nlike the fan $s$ in the northern area, pedofacies relationships, both on the fans and on the floodplains, are clearly secn. Palaeosols also developed on the exposed Jake margins, and floodplain pond carbon- ates. Local geological, climatic and geomorphological factors controlled the nature of the soilscape in the basin. The spatial distributions and stratigraphies of the palaeosols in the fans are different to those seen in many Quatemary fans where major climatic changes have led to discrete phases of stability (soil formation) and instability .

Soils are integral pans of landscapes. Palaeosols in ancient continental deposits can be used to assess the controis on the geomorphological evolution of an area, and the roles of local factors versus external ones such as climatic change.

\section{ACK NOW LE DG MENTS}

We wish to thank Drs H. and S. Ordonez, M. Hoyos and M.E. Sanz for discussions of the Madrid Basin. P. Silva, A. Cross and J. Watkins are thanked for providi ng assistance with the preparation of the manuscript and illustrations. We sincerely thank $\mathbf{M}$. Kraus (Boulder) and N . Platt (Berne) for their construct ive and incisive reviews of an earlier version of th is paper. University of Reading, P.R.I.S. contribution 162.This work was financed by the project PB89-0032.

\section{REFERENCES}

ALBERDI, M.T., Hovos, M., ]UNCO, F., LoPEZ-MARTINEZ , N., MORALES, J., SESE, C.\& SORIA, O.(1983)Biostratigraphie et évolution sédimentaire du Néogene continental de l'aire de Madrid. Médit. Neog. Cont. Palaeoenvironm., lnterim Coll., Montpellier, pp. 15-18.

ALONSO ZARZA. A.M.( 1989) Estudio petrolitologico y sedimentológico de las Facies de abanicos alluvialess del Neogeno en el sector NE de la Cuenca de Madrid y su relacion con las Facies mâs centrales, provincia de Guadalajara. Thesis, Uni. Complutense, Madrid, 473 pp. 
ALONSO, A.M., CALVO. J.P. \& GARCIA DEL CURA, M.A. (1986) Sedimentología y petrología de los abanicos alu viales y facies adyacentes en el Neôgeno de Paracuellos de Jarama (Madrid). Estudios geol., 42, 79-101.

ALONSO, ZARZA, A.M.. CALVO, J.P. \& GARCIA DEL CURA, M .A . (1992) Palcogcomorphological controls on the distribution and sedimemary styles of alluvial systems, Neogcnc of the northeast of the Madrid Basin (central Spain). Spec.pubis int.Ass. Sedimenr. (in press).

ALONSO ZARZA, A.M.. CALVO, J.P., GARCIA DEL CURA, M.A \&\& HoYOS, M.(1990) Lossistemasaluviales Miocenos del borde noreste de la Cuenca de Madrid; sector CifucmcsLas Inviernas (Guadalajara) Revta Soc. geol. Esp.,3, 213 229.

ALONSO ZARZA, A.M., GARCIA DEL CURA, M.A. \& CALVO, J.P. (1988) Significado paleogeografico de las texturas y acumulaciones de carbonatos en perfiles edaficos de la Unidad Tntermedia del Mioceno de la Cuenca de Madrid (prov. de G uadalajara). Geogaceta, 5, 30-33.

BESLY, B.M . \& FIELDING, C.R . (1989) Palaeosols in Westphalian coal-bearing red-bed sequences, central and northern England. Palaeogeogr. Palaeoclimatol. Palaeoecol.,70, 303-333.

BowN, T.M. \& KRAUS, M.J . (1987) Integration of channel and floodplain suites i n aggrading alluvial systems. I. Developmental sequences and Lateral relalions of lower Eocene alluvial palaeosols, Willwood formation, Bighom basin, Wyoming. J . sedim. Petrol., 57, 589-601.

BLAIR, T.C., CLARK, J.S. \& WELLS, S.G. (1990) Quaternary continental stratigraphy, landscape evolution, and application to a rcheology. Jarilla piedmont and Tularosagraben floor, White Sands Missile Range, New Mexico. Bull.geol. Soc. Am, 102, 749-759.

BLANK, R.R. \& fOSBERG. M.A. (1990) Micromorphology and classification of secondary calcium carbonate accumulations that surround or occur in the undersides of coarse fragments in fdaho (USA). $\mathrm{n}$ :Soif Micromorphol- ogy; a Basic and App/ied Science, Developments in Soi/ Scie11ce, Vol. 19 (Ed. by L. A . Douglas), pp. 341-346. Elsevier, Amsterdam.

CALVO, J.P., ALONSO, A.M. \& GARCIA DEL CuRA, M.A. ( 1986) Depositional sedimentary controls on sepiolite occurrence in Paracuellos de Jarama, Madrid Basin. Geogaceta, 1, 25-28.

CALVO, J.P., ALONSO ZA.RZA, A.M. \& GARCIA DEL CURA, M.A . (1989) Models of Miocene marginal lucustrine sedimentation in response to varied depositional regirnes and source areas in the Madrid Basin (central Spain). Palaeogeogr. Palaeoclimatol. Paaaeoeco/., 70, 199-2 14. CHADW ICK, O.A..SOWERS, J.M.\& AMUNDSON, R.0.(1989) Morphology of calcite crystals in clast coalings from four soils in the Mojave Desert region.Soil Sei. Soc.Am. J., 52, 21 1-219.

CHRISTENSON, G.E. \& PURCELL, C.(1985) Correlation and ageof Quaternary alluvial-fan sequences, Basin and Range province, southwestern United States. Spec. pop. geai. Soc. Am., 203, 115-122.

DE VICENTE, G., CALVO, J.P. \& ALONSO ZA.RZA, A.M. (1990) Main sedimentary units and related strain fields of the Madrid basin (central Spain) during the Neogene. IX Congr. RCM NS, Abstracts. Inst. Paleont. M. Crusafont, Barcelon a, pp. 121-122.
DORN, R.l., DENLRO, M.J. \& AHE, H.O. (1987) Isotopie evidenccof climaticinfluence on alluvial-fan developrnent in Death Valley. CaJifornia. Geology, 15, 108-110.

FRENCH. R.H. (1987) Hydra11/ic Processes on Aluvial Fans. Elsevier, Amsterdam .

FREYTET, P. \& PLAZIAT, J.C. ( 1982) Continental carbonate scdimentation and pedogenesis-Late Cretaccous and early Tertiary of southem France. Co111r.Sedimenrol., 12, 213 pp. GARCIA DEL CURA, M.A., ORDOÑEZ, S.\& CALVO. J.P.(1986) La Unidad salina (Mioceno) en al arca de Madrid, caracteristicas petrolôgicas y mineral6gicas. Bol.Soc. füp. $M$ i11eralogia, 9,329-338.

GA.RCIA DEL CURA, M.A., ORDOÑEZ, S.\& LOPEZ-AGUAYO, F. ( 1979) Estud io petrol6gico de la "Unidad Salina" de la Cuenca del Tajo. Estudios geol., 35, 325-339.

GERRARD.A.J. (1981) Soils a11d landforms. Allen \& Unwin, London, 219pp.

GILE, L.H. (1977) Holocene soils and soil-geomorp hic relations in a semi-arid region of Southern New Mexico. Quat. Re., 7, 112-132.

GILE, L.H., HAWLEY, J.W. \& GROSSMAN, R.B. (1981) Soils and Geomorphology in tire Basi11 and Range area of soulhem New M exico-G11idebook to the Desert Project, Memoir 39. New Mexico Bureau of Mines \& Minerai Resources.

GILE, L.H., PETERSON, F.F. \& GROSSMAN, R.B. (1966)

Morphological and genetic sequences of carbonate accumulation in desert soils. Soi/ Sei., 100, 347-360.

HAR VEY, A .M. (J 984). Aggradation and dissection sequences on Spanish alluvial fans: influence on morphological developrnent. Catena, 11.289-304.

HARVEY, A .M . (1987) Alluvial fan dissection :relationships between morphology and sedimcntation. Ln:Desert Sedime111s: Ancienr a11d Modem (Ed. by L. Frostick \& Reid), Spec.pubis geol. Soc. Lond., 35, 87-J 03.

HARVEY, A.M . (1989) The occurrence and role of arid zone fans. In : Arid Zone Geomorphology (Ed. by D. S. G. Thomas), pp. 136-158. Belhaven Press.

HARVEY, A.M.(1990) Factors influencing Quaternary alluvial fan development in southcast Spain. In: Alluvial Fans: A

Field Approach (Ed. by A . H. Rachocki \& M . Church), pp. 247-269. John Wiley \&Sons, London.

HAY, R.L.\& WJGGJNS, B. ( 1980) Pellets, ooids, sepiolite and silica in three calcretes of the southwestern United States. Sedime1110/ogy, 27, 559-576.

LG.M.E. (1989) Hoja Geo/Ogica de Madrid (559). Mapa Geológico deEspa.na 2•serie, $71 \mathrm{pp}$.

l.G.M.E.(1991) Hoja Geologica de Villaviciosa de Odon(558).

Mapa Geológico de Espana 2" serie (in press).

JONES, B. \& SQUAIR, C.A. ( 1989) Formation of peloids in plant rootlets, G rand Cayman, British West Indics. J. sedim. Petrol., 59, 1002-1007.

JuNco, F. \& CALVO, J.P. (1983) Cuenca de Madrid. In : Geologia de Espaiia, Libro Jubilar J .M. Rios, IG ME, 2, pp. 534-543.

K RAUS, M.J . (1991) Tertiary paleosols. Ln : Rocks and Soifs (Ed. by W. Chesworth \& !. P. Martini). Elsevier, Amsterdam (in press).

LATTMAN, L.H. (1973) Calcium carbonate cementation of alluvial fans in southern $\mathrm{N}$ evada. Bull . geol . Soc. Am., 84, 30 $13-3028$ 
LECCE, S.A. (1990) The alluvial fan problem. In : Alluvial Fans: A Field Approach (Ed. by A. H. Rachocki \& M . Church), pp. 3-24. John Wiley \& Sons, London.

LETTIS, W.R. (1985) Late Cenozoic straùgraphyand structure or the west margin or the central San Joaquim Valley, California. Spec.pap.geol. Soc. Am., 203,97-114.

MACHETTE, M.N. (1985) Calcic soils or the southwestern United States. Spec.pap .geol.Soc.Am., 203, 1-21.

MAZZULLO, S.J \& BIRDWELL, B.A. (1989)

Syngenetic

formation of grainstones and pisolites from renestral carbonates in peritidal settings. $J$ .sedim. Petrol., 39, 605-61 1.

McCRAW, J .O. (1968) The soil pauem of some new Zealand

alluvial fans.

4.pp.

631-640.

McGRATH. D.B. \& HAWLEY, J.W. (1987)

Geomorphic

evolution and soil geomorphicrelationships in theSocorro area, central new Mexico. In : Guidebook 10 the Socorro Areu of New M exico (Ed. by V. T. McLemore \& M. R. Bowie), pp. 58-67. New Mexico Bureau of Mines \& Minerai Resources.

MEGIAS, A.G.(1982). Introduccion al anâlisis tectosedimen- tario: Aplicacion al estudio dinâmico de cuencas. ln : $V$ Congreso La tilloamericano de Geología. Buenos Aries, Actas, 1, pp. 385-402.

MEGIAS, A.G., ORDOÑEZ, S. \& CALVO, J.P.(1983)

Nuevas

aportaciones a l conocimiento geológico de la Cuenca de Madrid. Rev. Mat. Proc. Geol., 163-191.

N ETTERBERG, F. (1969) Thegeologyand engineeringproperties of So111/r Africa11 calcretes. PhD thesis, University of Witwatersrand.

NETTERBERG. F. (1980) Geology of Southern African calcretes:1.Terminology, description, macrofeatures, and classification. Tra11s. geo/ . Soc. S. Afr., 83.255-283.

NETILETON, W.0. \& PETERSON, F.F. (1983)

Aridisols. ln :

Pedoge11esis a11d Soif Taxonomy li-Tire Soil Orders (Ed. by L. P. Wilding, N. E. Smeck \& G. F. Hall), pp. 165- 215.Elsevier, Amsterdam.

ORDOÑEZ. S., GARCIA DEL CURA, M.A.

Hovas, M. \& CALVO, J.P. (1985) Middle Miocene paleokarst in the Madrid Basin (Spain) a complex karstic system. ln: 61/r

Eur. Reg. M tg. Sedimemol..Im. Assoc. Sed ., LJ eida. Abstr. (Ed. by J . Rosell, E. Remacha \& M. Zamorano), pp.624- 627.

PLAIT, N.H.(1989) Lacustrine carbonates and pedogenesis: sedimentology and origin of palustrine deposits of the Early Cretaceous Rupelo Formation, W. Cameros Basin,

N. Spain. Sedimentology, 36, 665-684.

RACERO, A. (1988) Consideraciones acerca de la evolución geológica del margen N W de la Cuenca del Tajo durante el Terciario a pa rt i r de los datos del subsuelo. In : II Congreso Geológico de España (Ed.by J.A. Vera). pp.213- 222.

REAMS, M.W . (1990) Stromatolitic humidclimate carbon- ates: a variety of calcrete? In : Soif Micromorp/10/ogy : a Basica11d Applied Science Developmems in Soif Science, Vol.

19 (Ed. by L. A. Douglas), pp. 395-400. Elsevier,

Amsterdam.

RETALLACK. G.J. (1990) Soifs of the Past. An Introduction ta Paleopedology. U nwin Hyman, London, 520 pp.

SCHUMM, S.A., MOSLEY, M.P. \& WEAVER, W.E. (1987)

Experimenial Fhwial Geomorplrology. Wiley, New York.

SMITH, R.M.H. ( 1990) A lluvial paleosols and pedofacies sequences in the Permian Lower Beau fort of the south- western Karoo Basin, South Africa. J. sedim. Petra/., 60, 258-276.

SOIL SURVEY STAFF ( 1975) Soif Taxo11omy: a Basic Sys1em of Soil Classificatin for Making and Interpreting Soif Survey. US Dept. of Agriculture Conservation Service, Agriculture Handbook No. 436. US Govt. Printing Office, Washing- ton, DC, 754 pp.

TALBOT, M.R.\& WILLIAMS, M.A. (1979) Cyclic allu vial fan sedimentation on the flanksof fùted dunes, Janjari, Central N iger.Catena. 6, 43-62.

WATTS, N.L. (1980) Quatemary pedoge nic calcretes from the Kalahari (southern A frica): petrology and regional sign ificance.Sedimemology, 27, 661-686.

WJEDER, M. \& YAALON, D.H. (1974) Elfect of matrix com position on carbonate nodule crystallization. Geo- derma, 11,95 121.

WRIGHT, V.P. (1983) A rendzina from the Lower Carboni- ferous of South Wales. Sedimentology, 30, 83-94.

WRIGHT, V .P. (1989) Terrestrial stromatolites and laminar

calcretes: a review. Sedime11t.Geol.,65, 1-13.

WRIGHT, V.P. (1990) Syngenetic formation of gra instones and pisolites from rencstral carbonates in peritidal seuings: discussion.J.sedim. Petrol..60, 309-310.

WRIGHT, V.P. (199 1) Paleopedology:stratigraphie relation- ships and empirical models. In : Rocks and Soifs (Ed. by W. Cheswort h \& 1. P. Martini). Elsevier, Amsterdam (in press).

WRIGHT, V.P.\& ALOl'SO ZARZA, A.M. (1990)

Pedostrati-

graph.ic models for alluvial fan deposits: a tool for interpreting ancicnt sequences. $J$ Geol.Soc.Lond., 147, 8- 10.

WRIGHT. V.P..PLAIT, N.H.\& WIMBLEDON, W.A. (1988)

Biogenic lam ina r calcretes:evidence of calcified root mat horizons in palcosols. Sedimentology,35, 603-20. 